\title{
The contribution of Richard M. Forester to the knowledge of the paleohydrologic and paleoclimatic significance of Cenozoic non-marine Ostracoda
}

\author{
An introduction to the Richard M. Forester memorial issue
}

\author{
Alison J. Smith • Emi Ito • B. Brandon Curry • \\ Patrick De Deckker
}

Published online: 6 September 2016

(C) Springer International Publishing Switzerland 2016

\begin{abstract}
Ostracodes (Class Crustacea) have long held place as one of the major groups of useful microfossils in stratigraphy, evolutionary biology, and paleoecology. Ranging in time from the Ordovician Period to the present day, these microscopic crustaceans have proven time and time again their value in applied geology and environmental studies. The non-marine ostracodes of the late Cenozoic Era (including modern populations) have been shown to be particularly useful in the fields of paleoclimate and paleohydrology, and
\end{abstract}

Guest editors: Alison J. Smith, Emi Ito, B. Brandon Curry \& Patrick De Deckker / Multidisciplinary aspects of aquatic science: the legacy of Rick Forester

A. J. Smith $(\bowtie)$

Department of Geology, Kent State University, Kent, $\mathrm{OH} 44242$, USA

e-mail: alisonjs@kent.edu

E. Ito

Department of Earth Sciences and the Limnological

Research Center, The University of Minnesota,

Minneapolis, MN 55455, USA

\section{B. B. Curry}

Illinois State Geological Survey, Prairie Research Institute, University of Illinois at Urbana-Champaign,

Champaign, IL, USA

P. De Deckker

Research School of Earth Sciences, The Australian

National University, Canberra, ACT 2601, Australia much of that success can be traced to the research efforts of Rick Forester of the United States Geological Survey (USGS). Rick passed away quite suddenly in March of 2014, following his early retirement from the USGS in 2005. This issue of Hydrobiologia will provide the reader with a view of the scope of his research interests, which were primarily in the areas of applied uses of ostracode records to solve problems in late Cenozoic paleoclimate and paleohydrology in North America. He frequently worked with specialists in diatoms and pollen, as well as hydrologists, hydrogeologists, and isotope geochemists, and these papers reflect his interests in these areas. His astonishingly extensive knowledge of geology, physical chemistry, statistics, and paleontology made him a unique figure in the geosciences, and his loss is deeply felt by his many colleagues.

Rick studied modern and Late Cenozoic distributions of non-marine ostracodes for their value in solving paleoclimatic and paleohydrologic problems. He was the founder of the public access database "NANODe" (www.kent.edu/nanode), a non-marine ostracode biogeographical database with species and associated hydrochemical data from about 600 sites in the United States, now also available through the public access multi-proxy database Neotoma (www. neotomadb.org). In paleoclimatic and paleoenvironmental research, a biological "proxy" is a taxon with known modern environmental tolerances and biogeographical distribution, and which also has a significant 
presence in the fossil record. Such a taxon can be used to estimate past conditions, and is a proxy for instrumental records, which typically do not extend more than about two centuries into the past. This concept of a suitable biological proxy for paleoenvironmental and paleoclimatic reconstructions is central to the established multi-proxy method in Quaternary studies.

Rick grew up in the small town of Hancock, New York, in the western Catskills. His family history was steeped in the culture of rural New York and the coal country of Pennsylvania around Scranton. His mother Ellen Forester taught in a one-room schoolhouse, and his father Clayton Forester owned the local newspaper, The Hancock Herald. Rick was the first in his immediate family to go to college. He received a B.S. in Geology from Syracuse University in 1969. He began graduate school at the University of Illinois, Urbana, supported through a Teaching Assistantship. He completed an M.S. on stable isotope geology in 1972 under Tom Anderson, and a Ph.D. on probability and ostracode ecology in 1975 under Philip Sandberg. Thus, by 1975, he had developed research expertise in three major areas of the geosciences: paleontology, statistics, and stable isotope geochemistry. While working as a teaching assistant at the University of Illinois CU Geology Department, Rick met and married Elisabeth Brouwers, currently a USGS Emeritus scientist and ostracode specialist. During their 15-year marriage, they published together several papers on estuarine ostracodes.

Following completion of his doctoral degree, he was awarded a National Research Council postdoctoral position with the USGS, to work with ostracode specialist Joseph Hazel on biostratigraphy of Miocene marine ostracodes. Upon completing the postdoctoral fellowship, he was hired as a Research Geologist by the U.S. Geological Survey in Denver, Colorado. His first research project was working with Tom Fouch and the USGS Energy Team on non-marine ostracodes from the Eocene Green River Formation in Utah (during these years, oil prices were at an all-time high, and the potential for developing the oil shales in the Green River Formation was of great interest). He spent considerable time learning the difficult systematics and paleoecology of non-marine ostracodes. It was during this time working on the Green River Formation that he became acquainted with two scientists who would significantly influence his future research: Denis Delorme of the Canada Center for Inland
Waters, a specialist in modern non-marine ostracode taxonomy and ecology who had assembled a vast database on ostracodes from Canadian inland waters, and Blair Jones, an outstanding geochemist and hydrologist at the USGS who had a special interest in the chemical evolution of brines in saline lake systems. Extensive conversations with Denis and Blair led Rick into a deeper understanding of the hydrogeochemical environment of non-marine ostracodes.

In the late 1970's and through the 1980's, Rick became involved in ongoing projects of the USGS into the paleoclimatic significance of pluvial lake records in the Great Basin of the United States (Fig. 1). Rick made significant discoveries about ostracode species distributions and hydrochemistry as he worked on these projects. This research resulted in his documentation of species' preferences in North America for particular solute pathways in saline lakes: that is, pathways of bicarbonate enrichment or bicarbonate depletion with rising salinity. In a series of papers published in the early 1980s, he linked the distribution of common species to the pathways described in the

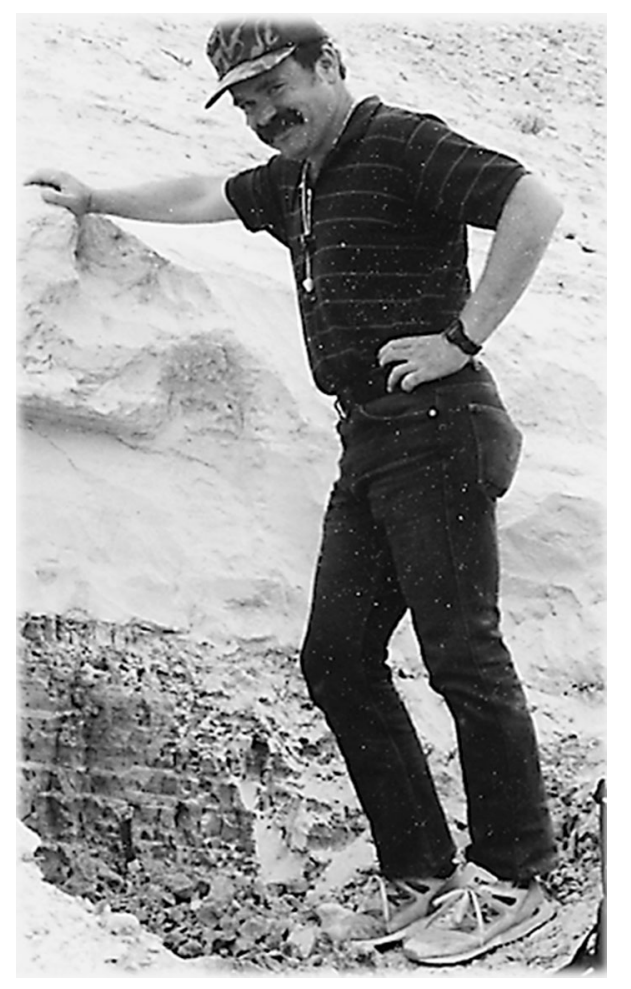

Fig. 1 Rick Forester in the 1980's, conducting fieldwork in the Great Basin. Photo provided courtesy of Robert S. Thompson, USGS 
solute evolution paper by Eugster \& Jones (1979). His earliest paper on this topic was a study with his colleague J. Platt Bradbury (diatom specialist and paleolimnologist, USGS) on the paleohydrologic significance of the ostracode and diatom records in Plio-Pleistocene paleolacustrine deposits in Beaver Basin, Utah (Forester \& Bradbury, 1981). Within just a few years, he was publishing an array of studies using ostracodes as paleoenvironmental indicators (Forester, 1983, 1985; Markgraf et al., 1984; Forester $\&$ Brouwers, 1985), culminating in a very significant paper (Fig. 2) published in Geology in 1986- "Determination of the Dissolved Anion Composition of Ancient Lakes from fossil Ostracodes" (Forester, 1986). In particular, he was able to demonstrate the link between Pliocene-Pleistocene ostracode distributions and solute pathways in lakes as a way to reconstruct not only changes in paleoclimate, but changes in past hydrology.

Rick consolidated his view of ostracode species as primary biological proxies of paleohydrologic conditions in his analyses of Pliocene through Holocene lake

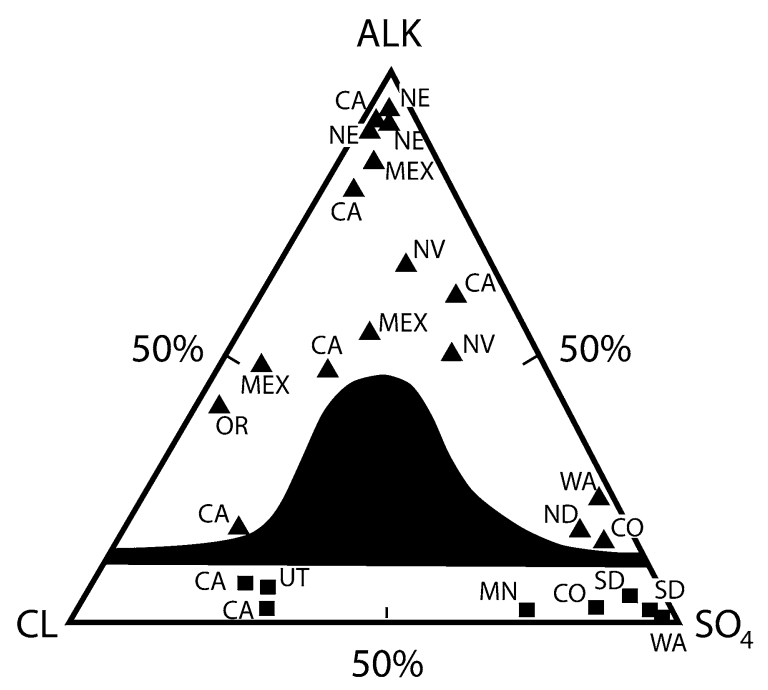

Fig. 2 Rick Forester linked solute chemistry and ostracode distributions in this 1986 landmark study: "Relative dissolved anion compositions in equivalent percentages for saline lakes in which either Limnocythere staplini (squares) or L. sappaensis (triangles) is living. U.S. states where lakes are located: $C A$ California, $C O$ Colorado, $M N$ Minnesota, $N D$ North Dakota, $N E$ Nebraska, $N V$ Nevada, OR Oregon, $S D$ South Dakota, UT Utah, WA Washington, MEX Mexico. Shaded area is defined by composition of saline lakes (unpublished data) where neither limnocytherean species has been found living." Redrawn from Forester, 1986, Geology, 14:796-798, Fig. 1 records in North America. Undoubtedly, two of his most significant contributions in applied ostracode studies were in deducing groundwater recharge, flowthrough, and discharge processes among lakes, springs, and wetlands in regional settings, as well as linking water pathways to meteorological conditions at continental scale. He consistently made use of Hutchinson's concept of niche space, the "n-dimensional hypervolume" (Hutchinson, 1957) to explore ostracode distributions in solute space. It was this understanding of species responding to solute changes, in combination with stable isotope and trace element studies in ostracode shells, that led to many research collaborations with Patrick De Deckker of the Australian National University, Emi Ito of the University of Minnesota, and Jay Quade of the University of Arizona. Together they expanded the field of knowledge in geochemical applications of carbonate microfossils. Ultimately, Rick changed the way most ostracode workers do science, and yet he stayed quietly in the background, preferring to work informally with colleagues and not draw attention to himself. Rick's interests were very extensive as, for example, he developed an interest in charophytes [macrophytic algae] and their mineralized reproductive cases, again of use in paleohydrologic reconstructions. He also explored the ostracode taxa in oxygenated aquifers and spring discharge areas in western North America, discovering new species and novel assemblages.

In the final decade of his career at the USGS, he became Technical Principal Investigator of the Yucca Mountain Climate Program, bringing his broad experience and knowledge to the problem of determining the record of past hydrologic conditions over the most recent 400,000 years in the southwestern United States, and particularly in the Yucca Mountain region of southern Nevada. During this time he produced two Yucca Mountain Project Milestone reports with coauthors on the hydrology and the climatology of the Yucca Mountain region (Forester et al., 1996, 1998). Both reports reflect his remarkable ability to synthesize relevant yet disparate kinds of information over large spatial and temporal scales.

In 2005, Rick was nominated and elected by his peers as a Fellow of the American Association for Advancement of Science for meritorious efforts to advance science in the fields of past climate and hydrology, in particular working with non-marine ostracodes. He authored over 100 professional 
publications and reports during his career. He served on numerous Ph.D. committees, a tribute for someone not in academia. He mentored many graduate students on the identification and the ecological and hydrochemical significance of non-marine ostracode assemblages and inspired a new community of non-marine ostracode workers in North America and overseas. He was passionate about the graduate students he helped and his commitment to their science and well-being continued well after their graduation. His generosity with his time, his open handedness with scientific ideas, and his wry sense of humor impressed all who worked with him. He never missed an opportunity to help students and colleagues towards scientific advancement. The topics in the papers that follow reflect the range of his interests and impact in the geosciences.

\section{References}

Eugster, H. \& B. F. Jones, 1979. Behavior of major solutes during closed-basin brine evolution. American Journal of Science 279: 609-631.

Forester, R. M., 1983. Relationship of two lacustrine ostracode species to solute composition and salinity: Implication for paleohydrochemistry. Geology 11: 435-438.
Forester, R. M., 1985. Limnocythere bradburyi n. sp. A modern ostracode from central Mexico and possible Quaternary paleoclimatic indicator. Journal of Paleontology 59: 8-20.

Forester, R. M., 1986. Determination of the dissolved anion composition of ancient lakes from fossil ostracodes. Geology 14: 796-799.

Forester, R. M. \& J. P. Bradbury, 1981. The paleoenvironmental implications of the ostracodes and diatoms from selected samples in Pliocene and Pleistocene lacustrine sediments in the Beaver Basin, Utah, U.S. Geological Survey Open File Report 81-390: 1-44.

Forester, R. M. \& E. M. Brouwers, 1985. Hydrochemical parameters governing the occurrence of estuarine and marginal estuarine ostracodes: An example from South Central Alaska. Journal of Paleontology 59: 344-369.

Forester, R. M., J. P. Bradbury, C. Carter, A. B. Elvidge, M. L. Hemphill, S. C. Lundstrom, S. A. Mahan, B. D. Marshall, L. A. Neymark, J. B. Paces, S. E. Sharpe, J. F. Whelan \& P. E. Wigand. 1996. Synthesis of Quaternary response of the Yucca Mountain unsaturated and saturated zone hydrology to climate change. U.S. Geological Survey - Yucca Mountain Project Branch 1996 Milestone Report 3GCA102M: 1-110.

Forester, R. M., J. P. Bradbury, J. F. Whelan, P. Fransioli \& G. Prowell, 1998. Site description document climatology and meteorology chapter 3.4. Yucca Mountain Project Branch Milestone Report SPC323M4: 1-99.

Hutchinson, G. E., 1957. Concluding remarks, cold spring harbor symposium. Quantitative Biology 22: 415-427.

Markgraf, V., J. P. Bradbury, R. M. Forester, G. Singh \& R. S. Sternberg, 1984. San Agustin Plains, New Mexico: age and paleoenvironmental potential reassessed. Quaternary Research 22: 336-343. 